\title{
ANARCHOFEMINIZMUS O PRÁVE: POČIATOK, SÚČASNOSŤ, BUDÚCNOSŤ1
}

\section{ANARCHA-FEMINISM ON LAW: PAST, PRESENT AND FUTURE}

\section{Dominik Šoltys ${ }^{2}$}

DOI: https://doi.org/10.24040/pros.13.11.2020.sdtsp.64-90

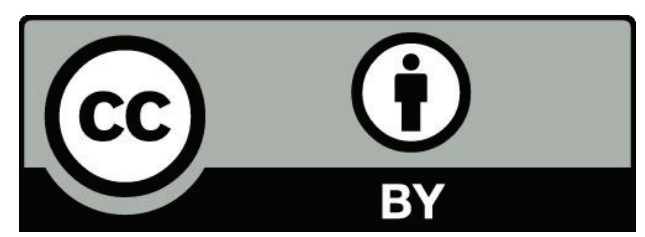

\begin{abstract}
Abstrakt
Predložený príspevok sa zaoberá prístupom anarchistického feminizmu k právu ako regulátor spoločenských vzt’ahov. V tejto súvislosti je potrebné poukázat' na kritický a odmietavý prístup anarchofeministických autoriek $k$ právnej regulácii postavenia žien ako jedného z hlavných zdrojov rodovo podmieneného útlaku. Príspevok $v$ stručnosti predstavuje najkritizovanejšie spoločenské a právne inštitúcie (manželstvo, rodina, rodičovstvo, právna úprava týkajúca sa telesnej integrity jednotlivcov, atd'.), ktoré sa objavujú naprieč anarchofeministickým myslením od 19. storočia po súčasnost'. Obvlášt’ sa zameriava na anarchistický/anarchofeministický postoj $k$ právu, ktorý odmieta právo ako a priori škodlivý (mocenský) nástroj regulácie spoločenských vztahov.
\end{abstract}

\section{Kl’účové slová}

anarchizmus, anarchofeminizmus, rodový útlak, žena, právo

\begin{abstract}
The study deals with the anarcha-feminist approach to law as a factor of social relations regulation. In this context, it is necessary to point out the critical and negative view of almost all anarcha-feminist authors, who consider the legislation on the status of women as one of the main sources of gender-based oppression. The study also briefly presents the most frequent critiques of social and legal institutions (marriage, family, parenthood, laws providing the regulation of body, etc.) from the 19th century to the present days. In particular, the study is focused on the anarchist/anarcha-feminist attitude towards the law as a priori abusive (based on power) factor of social regulation.
\end{abstract}

\section{Keywords}

Anarchism, Anarcha-feminism, Gender-based Oppression, Woman, Law

\footnotetext{
1 Tento príspevok predstavuje čiastkový výsledok riešenia projektu Vega č. 1/0386/19 - Nové dimenzie metodológie právnej argumentácie - Úloha právnych princípov vo viacúrovňovom právnom systéme.

2 JUDr. Dominik Šoltys, PhD., Právnická fakulta Univerzity Pavla Jozefa Šafárika v Košiciach - Ústav teórie práva Gustava Radbrucha, odborný asistent.
} 


\section{PRÁVNE ROZPRAVY ON-SCREEN II. - Sekcia dejín a teórie štátu a práva}

online vedecká konferencia - 13. november 2020

\section{Úvod}

Anarchofeminizmus ako súčast' feministického myslenia do svojho vnútra vstrebáva anarchisticky boj proti mocenskej nadvláde štátu, ktorý následne predstavuje na pozadí feministického boja proti patriarchátu. To znamená, že anarchofeminizmus predstavuje feministickú myšlienkovú líniu, kde odstránenie patriarchálneho útlaku je podmienené odstránením štátu a akéhokol'vek hierarchického modelu spoločenských vzt’ahov. Je náročné v úvode definovat' presne a jednoznačne anarchofeminizmus. Treba vziat' do úvahy najmä časové hl'adisko, tzn. dobu, vktorej anarchofeminizmus vznikol a vyvíjal sa, ako aj ideologickú pestrost', ktorú sa snaží vo svojom vnútri vyjadrit'. Treba si však uvedomit', že anarchofeminizmus vyslovuje presvedčenie, že k plnohodnotnému oslobodeniu žien môže dôjst' až odstránením všetkých podôb útlaku. Už z toho vyplýva, že anarchizmus je predovšetkým kritickou feministickou mocou. Aj z tohto dôvodu začíname náš príspevok o postavení kategórie moci v feminizme a robíme základné vymedzenia v prístupe feminizmu $\mathrm{k}$ moci a v prístupe anarchofeminizmu k moci. Ďalej pokračujeme rozlíšeným dvoch podôb anarchofeminizmus, ktoré vznikli a vyvinuli sa v rozdielnych historických dobách. V tejto súvislosti tak predstavuje ich spoločné ako aj rozdielne znaky. Zároveň prechádzame k ciel’u nášho príspevku, ktorým je vymedzit’ vzt’ah anarchofeminizmu k práva.

\section{Stručne o probléme moci v rámci feminizmu}

Už v minulosti ako aj v súčasnosti vždy existovali feministky, ktoré sa viac alebo menej zaoberali otázkou prejavov moci a štátu ako faktorov útlaku voči ženám. V nadväznosti na to sa snažili podat' kritické vysvetlenia toho ako štát prispieva $\mathrm{k}$ nerovnému postaveniu žien v spoločnosti a akými (všemožnými) spôsobmi sa tento status quo udržiava. V tejto súvislosti však vôbec nemusíme hovorit' o feministických predstavitel'kách z radu anarchofeminizmu. Takmer $\mathrm{v}$ každej politickej, sociálnej a právnej teórii feminizmu sa stretávame s kritikou patriarchátu ako konceptu, ktorý je podopretý mocou a potvrdený štátnou politikou. Táto kritika si berie na zretel’ kategórie, akými sú moc, donútenie a násilie, nadvláda, panujúca hierarchia v spoločenských vzt’ahoch, ale aj samotné právo. Kritický prístup k týmto kategóriám je prítomný naprieč diverzitnými feministickými prístupmi a rôznymi feministickými autorkami. V skutočnosti teda nájdeme analýzu moci v radikálnom, 


\section{PRÁVNE ROZPRAVY ON-SCREEN II. - Sekcia dejín a teórie štátu a práva}

online vedecká konferencia - 13. november 2020

kultúrnom, socialistickom, marxistickom psychoanalytickom, lesbickom, rasovom a etnickom feminizme, ekofeminizme, atd'., atd'. Napríklad, takmer celý radikálny feminizmus je o kritike moci ako hlavnej opornej kategórie patriarchátu, teda podoby spoločnosti, kde štát, právo, ekonomický systém, morálka, tradície a zvyky vyjadrujú mocensky dominantné postavenie mužov nad ženami. Rovnako takmer celé dielo radikálnej feministky Catherine MacKinnon je analýzou moci v podmienkach patriarchálneho štátu a práva. MacKinnon tvrdí, že účelom feministickej teórie je politický problém mužskej moci nad ženami, ktoré ostatné politické teórie potláčajú alebo ignorujú. ${ }^{3} \mathrm{~V}$ podobnom duchu pripomína feministka a politická teoretička Cole Pateman, že „,[mužská] nadvláda nad ženami je presne tým problémom, s ktorým sa zaoberal feminizmus od neskorého sedemnásteho storočia, ale feministické spisovatel'ky neboli nikdy zahrnuté do kanónu politickej teórie, a súčasný feminizmus len pomaly a znovu obnovuje túto tradíciu feministických myšlienok. “4 Za doplnenie takisto stojí pozícia radikálnej feministky Marilyn French, ktorá kritizuje súdobú podobu patriarchálnej moci a navrhuje vytvorit' nový svet, ktorý sa po odstránení moci z spoločenských vzt'ahoch bude opierat' o opak moci, teda radost' (pleasure). ${ }^{5}$

Podobnú potrebu redefinície moci možno nájst' aj v myslení spiritualistickej ekofeministky Starhawk. Jej koncept spirituality Zeme (Earth-based spirituality) počíta aj s kritickou analýzou moci a konštruktívnym návrhom jeho prekonania. Podl’a Starhawk v súčasnosti dominuje chápanie moci v zmysle „moc nad niečím“, ktorú označuje ako „mocnad“ (power-over). Takýto zmysel moci vytvára hierarchiu, v ktorej sú jednotlivé časti jej štruktúry vzájomne oddelené a usporiadané vzt’ahom nadradeného k podriadenému. Naopak, podl'a nej sa ekofeminizmus snaží o zmenu štruktúry moci, ktorú Starhawk označuje ako „,moc-od-do" (power-from-within). Podstata takéhoto chápania moci sa ukrýva v tom, že táto

\footnotetext{
3 MacKinnon chápe rozlišovanie medzi mužom a ženou ako rozdiel, ktorý súvisí s politickou perspektívou nerovného prerozdeleným moci medzi oboma pohlaviami: „Feminizmus nemá svoju vlastnú teóriu štátu. Má však teóriu moci: sexualita je závislá od rodov tak ako sú rody závislé od sexuality. Mužské a ženské sú výtvorom erotizácie nadvlády a podriadenia sa. Rozdiel medzi mužom a ženou a rozdiel medzi nadvládou a podriadením sú vzájomne dynamicky vymedzené. [...] Feministická teória poznania je neoddelitel'ná od feministickej kritiky moci, pretože mužský pohl'ad sám seba nadrad'uje nad tento sveta ako jediný možný spôsob jeho pochopenia.“ Pozri MACKINNON, C. A.: Feminism, Marxism, Method, and the State: Toward Feminist Jurisprudence. In: Signs, Vol. 8, No. 4, 1983. s. 635 a nasl.

${ }^{4}$ Pozri PATEMAN, C.: Sex and Power. In: Ethics: An International Journal of Social, Political, and Legal Philosophy, Vol. 100, No. 2, 1990. s. 399.

${ }^{5}$ Podl'a Marilyn French je moc negatívna a deštruktívna hodnota. Moc sa preto k pozitívnym hodnotám, akými sú, napríklad krása (beauty), láska (love) a potešenie (pleasure), javí ako ich opozitum. V nadväznosti na to sa vyjadruje nasledovne: „Opozitom potešenia je moc, ktorá vyžaduje aby Ja bolo uzavreté pred l'ud'mi a udalost’ami vonkajšieho sveta a nezohl'adňovali sa v rámci sledovaného účelu [moci]." Pozri bližšie FRENCH, M.: Beyond Power: On Women, Men and Morals. New York: Summit Books, 1985. s. 338 a nasl, 540.
} 


\section{PRÁVNE ROZPRAVY ON-SCREEN II. - Sekcia dejín a teórie štátu a práva}

online vedecká konferencia - 13. november 2020

moc je mocou toku energie, ktorá preniká všetkým a všetko spája a vytvára zo všetkého jeden integrálny celok v podobe rovnostárskej duchovnej komunity. ${ }^{6}$

Teoretické sklony socialistického a marxistického feminizmu k analýzam moci upozorňuje aj anarchofeministka Lizzie Borden, podl'a ktorého väčšina socialistických a marxistických feministických predstaviteliek dospeli k odmietnutiu moci ako takej. ${ }^{7} \mathrm{Aj}$ ked' názor Borden môže byt' v skutočnosti diskutabilným, predsa len jej nemožno upriet', že pôvodné ženské predstavitel'ky marxizmu, socializmu či komunizmu - medzi ktorými nájdeme aj Rosu Luxemburg, Alexandru Michajlovnu Kollontaj, Claru Zetkin, a Angelu Balabanoff, Fredericu Montseny a d'alšie - sa vo svojich dielach z vel'kej časti (explicitne či implicitne) venujú analýze moci, od ktorej sa následne odrážajú pri formulácii svojich záverov. Podl’a Borden sú hlavnými príčinami vytvorenia kritiky moci u týchto autoriek negatívne dôsledky byrokracie, autoritarizmu a spôsobu realizovania ciel'ov Vel'kej októbrovej revolúcie v Rusku.

Uvedený stručný exkurz naprieč prístupmi feminizmu k moci ako takej nás privádza k otázke: $\mathrm{v}$ čom spočíva rozdiel medzi anarchofeministkým prístupom $\mathrm{k}$ moci a prístupmi naprieč ostatnými podobami feminizmu, respektíve existuje medzi nimi rozdiel? Samozrejme, tento rozdiel medzi nimi existuje a možno ho vymedzit’ nasledovne: anarchofeminizmus odmieta moc, a tým pádom akúkol’vek podobu hierarchicky usporiadaných spoločenských vzt'ahov, a to v absolútnych súvislostiach; naopak, feminizmus môže mat' viac alebo menej negatívnejší postoj $\mathrm{kmoci}$, ale rozhodne nesmeruje kodmietnutiu moci ako takej. Anarchofeminizmus sa zakladá na anarchistickom východisku, ktoré sa zhoduje $\mathrm{s}$ presvedčením, že moc človeka nad človekom je bez ohl'adu na svoju podobu a účel sociálnym zlom, a teda, že moc je príčinou každého spoločenského utrpenia na tomto svete. Anarchofeminizmus zvlášt’ pripomína, že medzi sériou mocenských útlakov nájdeme aj útlak voči ženám. Nadväzujúc na uvedené, anarchofeminizmus odmieta štát ako najvyššieho predstavitel'a (politickej) moci. A pretože právo je formalizovanou mocou štátu, rovnako odmieta aj jeho. Takýto prístup však nie je typickým pre zvyšok feminizmu. Feminizmus zo svojej teoretickej podstaty neodmieta moc ako takú; s mocou nad’alej vo svojich teóriách pracuje a snaží sa ju využívat' vo svoj prospech, resp. snaží sa ju korigovat' do podoby želaného politického usporiadania spoločnosti a spoločenských vzt'ahov medzi pohlaviami

\footnotetext{
${ }^{6}$ Pozri STARHAWK.: Dreaming the Dark: Magic, Sex \& Politics. Boston: Beacon Press, 1988. s. 35.

${ }^{7}$ Pozri viac BORDEN, L.: Women and Anarchy In: Heresies: A Feminist Publication on Art and Politics, Vol. 1, 1977, Iss. 2. s. 71-77.
} 


\section{PRÁVNE ROZPRAVY ON-SCREEN II. - Sekcia dejín a teórie štátu a práva}

online vedecká konferencia - 13. november 2020

alebo rodmi. Feminizmus tak prijíma a využíva moc $\mathrm{v}$ teórii a praxi, pretože chápe ako ju môže využit' v prospech zrovnoprávnenia žien. Navyše feminizmus neodmieta ani štát ako taký; odmieta iba patriarchálnu podobu štátu a patriarchálnu politiku štátu, t.j. štát, ktorý sa ideologicky opiera o nadradenost' muža a podradnost' ženy a za týmto účelom zavádza, presadzuje a udržiava patriarchálny politický, ekonomický, právny a širší sociálny rámec. Ako zhrnutie vyššie predstavených myšlienok možno uviest' skutočnost', že feminizmus sa v mnohom spolieha na štát a právo.

Jednoznačne to vedie kideologickým nezhodám medzi anarchofeminizmom a zvyškom feminizmu. Ako príklad možno uviest' kritické myšlienky kanadskej anarchofeministky a sociologičky Nicole Laurin Frenette voči feminizmu ako takému, a najmä voči feministickým optimistickým nádejam voči štátu. Podl'a nej v priebehu 20. storočia vysvitlo, že zmena štruktúry spoločenskej kontroly je plne v kompetencii štátu a štátnych inštitúcií. To sa plnohodnotne dá podl'a Frenette tvrdit' aj o feministických požiadavkách. Štát a štátne inštitúcie preberajú do svojich politík mnohé feministické princípy a činia tak za súhlasu a účasti žien alebo dokonca feministiek samých. Frenette je však proti feministickej stratégii spriahnutia sa so štátom, pokial' ide o feministické ciele. Podl'a nej sa tým len a len posilňuje štát a najmä sa tým posilňuje jeho „schopnost' kontrolovat’ ženy a ich hnutia. “8 Smerodajným pre politiku feminizmu by pre ženy a feministky mala byt’ predovšetkým individuálna sloboda žien, ktorá je nevyjadritel'ná mocou štátu a ktorá je na hony vzdialená spoločnost’ou predpokladaného ideálu ženskosti. Lepšie povedané, individuálna ženská sloboda je v prudkom rozpore so štátom a spoločensky dominantným ideálom ženskosti. Tieto slová, ktoré vyslovila začiatkom osemdesiatych rokov 20. storočia sú v kontraste s vtedajšou ale aj súčasnou feministickou stratégiou, ktorá sa snaží využívat' štát, vnútroštátne a medzinárodné právo ako hlavné spôsoby presadzovania požiadaviek ženského zrovnoprávnenia. $^{9}$

\footnotetext{
${ }^{8}$ FRENETTE, N. L.: On the Women's Movement. In: Our Generation, Vol. 15, 1982, No. 2. s. 33, 37 a nasl.

${ }^{9}$ Vo feminizme ako takom sa môžeme stretnút' u jednotlivých autoriek aj s krajným - a skôr ojedinelými podobami využitia moci štátu a práva $\mathrm{v}$ prospech feminizmu. V nadväznosti na uvedené možno poukázat’ na niektoré myšlienky radikálnej lesbickej feministky Sally Miller Gearhart. Táto feministická autorka priamo počítala s možnost’ou exkluzívneho prevzatia moci ženami, ktoré by vyústilo v nastolenie istej podoby matriarchátu. $\mathrm{K}$ feministkám a ženám sa prihovárala s tým, že je načase „začat' uvažovat' o tom, že karta sa obráti, o výmene moci, o vybudovaní ideológie ženského prvenstva a kontroly. Jednoduchá spravodlivost' podnecuje $\mathrm{k}$ tomu, že ak muži boli pri moci dlhé tisícky rokov a zbabrali prácu s l'ud'mi a environmentálnym zdravím, je načase dat' šancu inej alternatíve." MILLER GEARHART, S.: The Future - If There Is One - Is Female. In: MCALLISTER, P.: (ed.) Reweaving the Web of Life: Feminism and Nonviolence. Philadelphia: New Society Publishers, 1982. s. 274.
} 


\section{PRÁVNE ROZPRAVY ON-SCREEN II. - Sekcia dejín a teórie štátu a práva}

online vedecká konferencia - 13. november 2020

\section{Dve podoby anarchofeminizmu s ohl'adom na časové hl'adisko ich vznik a d'alšieho vývoja}

Anarchofeminizmus má vo svojom vnútri dve vývojové etapy, ktoré sa podstatne líšia nielen dobou ich vzniku a formovania, ale najmä východiskovými myšlienkovými zdrojmi, ideologickými okolnost’ami, podmienkami doby, atd'. To znamená, že s ohl'adom na časové hl'adisko rozlišujeme dve podoby anarchofeminizmu: prvá podoba anarchofeminizmu, vznikla a vyvíjala sa behom 19. storočia a prelomu 19. a 20. storočia; druhá podoba anarchofeminizmu vznikla behom druhej vlny feminizmu v Spojených štátoch amerických a pretrváva do dnešných dní. Prvú podobu budeme označovat' pomenovaním historický anarchofeminizmus, zatial' čo druhú podobu anarchofeminizmu budeme označovat' ako súčasný anarchofeminizmus. Začnime teda stručnou charakteristikou znakov každej z nich, čím si vymedzíme aj ich konkrétne odlišnosti a v závere tejto časti nášho príspevku aj podobnosti.

Historický anarchofeminizmus sa vyvíjal na pozadí anarchistickej teórie 19. storočia. S ohl'adom na miesto jeho vzniku a vývoja môžeme tvrdit', že mal internacionalistický charakter a rovnako internacionalistické boli aj jeho zámery. Historický anarchofeminizmus rozvíjali ženy, ktoré sami seba označovali ako anarchistky a navyše sa s osobitým zretel’om venovali problému, ktorý bol v tom čase označovaný ako „ženská otázka“. Medzi takýmito autorkami môžeme nájst’ mená ako Emma Goldman, Voltairine de Cleyre, Louise Michel, Nathalie Lemel, Lucy Parsons či Charlotte Wilson. Zaujímavost'ou historického anarchofeminizmu 19. storočia a prelomu 19. a 20. storočia je skutočnost' - a na to treba zvlášt' upozornit' - , že žiadna z týchto autoriek samu seba nikdy neoznačila za feministku. Feminizmus bol ako pojem v tom období spätý s buržoáznym hnutím žien za volebné právo žien. Zmienené anarchistky sa voči nemu vymedzovali kriticky. Rovnako sa anarchisticky a buržoázny feminizmus líšili v témach ako aj spôsobe navrhovaného riešenia takzvanej ženskej otázky. Tematicky sa historický anarchofeminizmus sústred’oval na témy, akými boli manželstvo, materstvo, sexuálna a reprodukčná nesloboda ženy, zat’aženie domácimi prácami, nízke mzdy v priemysle pre ženy a prostitúcia. Dá sa tvrdit’, že v tomto smere bola historická podoba anarchofeminizmus vo svojej analýze ženského znevýhodnenia ovel’a hlbšia než boli požiadavky politického a právneho zrovnoprávnenia sufražetiek. Svojím spôsobom, 


\section{PRÁVNE ROZPRAVY ON-SCREEN II. - Sekcia dejín a teórie štátu a práva}

online vedecká konferencia - 13. november 2020

anarchistické autorky tým predznamenali témy, ktoré sa stali aktuálnymi až behom druhej vlny feminizmu.

Stredobodom záujmu prvých anarchofeministiek boli životy a periodicitne sa opakujúce (negatívne) skúsenosti chudobných žien pracujúcej triedy 19. storočia a prelomu dvoch storočí. Preto je niekedy možné bádat' viac, inokedy zase menej, vôl'u prvých anarchofeministiek vykreslit’ ženy robotníckej triedy ako určitú jednoliatu spoločenskú triedu. Zvlášt' to možno bádat', že práve tieto anarchofeministky častokrát zhodne analyzujú javy spoločenského a súkromného života, ktoré charakterizovali a spájali životy týchto žien. Všetky tieto javy, ktoré ich robili spoločensky nerovnými a upierali im slobodu sa výrazne týkali odsunutia žien do rodinného života či zahltenia domácimi a rodičovskými povinnost'ami, nerovnost' v manželskom živote, oklieštenej sexuality žien s apelom na jej reprodukčnú funkciu, či skrátka sploštené vnímanie ženy iba ako dievčat’a, manželky a matky. Naopak predmetom ostrej kritiky historického anarchofeminizmu bol idealizovaný viktoriánsky obraz ženy ako jemnej, nábožnej, cudnej, oddanej a poslušnej manželky či matky. Napriek tomu boj žien za zrovnoprávnenie nevyčleňujú ako samostatnú tému a samostatný revolučný boj. Úzko ho spájajú s bojom robotníckeho hnutia. V nadväznosti na to prvé anarchofeministky veria $\mathrm{v}$ revolučnú silu robotníckeho hnutia, do rúk ktorého častokrát vkladajú nádej na oslobodenie ženy spod útlaku. Inými slovami, ženskú otázku sa podarí vyriešit' len vtedy, ak sa podarí vyriešit’ robotnícku otázku.

V neposlednom rade tieto anarchofeministky zdôrazňujú zrovnoprávnenie života žien a liberačný potenciál ženskej autonómie, sexuálnu slobodu ako nevyhnutnú podmienku celkového oslobodenia žien, predstavujú obraz novej slobodnej a zrovnoprávnenej ženy, anarchistický obraz (l'úbostného alebo strohého a oddeleného mileneckého) vzt’ahu medzi mužom a ženou, ale aj nový prístup anarchistickej spoločnosti k žene. Osobitne sa niektoré z nich dotkli aj sexuálnej slobody žien aj témy homosexuality, ktoré vtedajšia spoločnost' vnímala ako tabu alebo považovala za zločin, chorobu či nemorálnost'. Avšak, už tieto prvé anarchofeministky si predstavovali pod skutočne slobodnou anarchistickou spoločnost'ou jedine takú, ktorá bezpodmienečne prijíma do svojho celku plnohodnotne slobodnú ženu.

Navyše historický anarchofeminizmus mal rôznorodé ideologické zdroje, z ktorých vznikol. Túto črtu odčerpal z anarchizmu ako takého, ktorý už v týchto obdobiach býval zdôvodňovaný vzájomne nezlučitel’nými ideológiami. Pripomína to aj súčasná teoretička anarchizmu a anarchofeminizmu L. Susan Brown, ked' tvrdí, že anarchizmus sa behom svojej 


\section{PRÁVNE ROZPRAVY ON-SCREEN II. - Sekcia dejín a teórie štátu a práva}

online vedecká konferencia - 13. november 2020

histórie opieral o východiska „mutualistov, kolektivistov, komunistov, federalistov, individualistov, socialistov, syndikalistov, feministov, ako aj mnohých d'alších. "10 V tejto súvislosti tak nie je ničím zvláštnym, že anarchofeminizmus tohto obdobia obsahuje východiska anarchokomunistickej teórie Emmy Goldman, individualistického anarchizmu Voltairine de Cleyre, socialistického anarchizmu Charlotte Wilson a Lucy Parsons, ktorý sa neskôr transformoval do podoby anarchokomunizmu. ${ }^{11}$ Jednoducho, anarchofeminizmus si v tomto období zachováva ideovú heterogenitu anarchizmu.

Prvé anarchofeministky nepoznali pojem patriarchátu v zmysle ako ho používajú feministky zhruba od šest'desiatych rokov 20. storočia do dnešných dní. Môže to mat' niekol'ko dôvodov: bud' tieto autorky nerozpracovali pojem, pod ktorý by mohli subsumovat' dobový sexizmus, a teda nepoznali súborné označenie, ktorým by bolo možné spojit' jednotlivé prejavy sexizmu do jednotného pojmu; alebo nepovažovali patriarchát za d’alší a samostatný systém útlaku, pretože ich zaujímal predovšetkým útlak politický, ekonomický, náboženský či spoločenský. Práve toto druhé vysvetlenie môžu indikovat' aj hlavné ciele kritiky ranných anarchofeministiek. Zo zhoršeného postavenia žien obviňujú štát, kapitalizmus, cirkev či spoločenskú morálku a konvencie. V tejto súvislosti považovali zhoršené postavenie žien za kombináciu týchto faktorov a nenapadlo im vyčlenit' patriarchát ako d'alší a samostatný systém útlaku tak, ako to robia dnešné anarchofeministky či feministky vo všeobecnosti.

Druhá podoba anarchofeminizmu vznikla v sedemdesiatych rokoch 20. storočia a je vel'mi úzko spätá s druhou vlnou feminizmu. Táto podoba nevznikla z anarchizmu ako takého, ale vyčlenila sa z radikálneho feminizmu spravidla znovuobjavením významu myšlienok Emmy Goldman pre feministické hnutie. Práve v tomto období vzniká aj samotný pojem anarchofeminizmus (anglický ekvivalent: „anarchofeminism“) ${ }^{12}$, respektíve synonymické pomenovania, ktoré majú rovnaký obsah a možno ich používat' zamenitel'ne.

\footnotetext{
${ }^{10}$ BROWN, L. S.: The Politics of Individualism: Liberalism, Liberal Feminism and Anarchism. Montreal New York - London: Black Rose Books, 1993. s. 160.

${ }^{11}$ Pokial' máme hovorit' o Lucy Parsons, zvlášt' treba pripomenút', že jej anarchistická a feministická teória je do istej miery prepletená s témou rasizmu v USA. Okrem uvedeného treba doplnit', že Charlotte Wilson ako popredná predstavitel'ka pôvodne britského anarchizmu nezotrvala na svojej anarchistickej pozícii a v roku 1906 sa pridala k sufražetkám a $\mathrm{k}$ obhajobe volebného práva žien. Vrátila sa fabiánskemu socializmu a ženskú emancipáciu hájila na medzinárodnej úrovni z pozície sociálnej demokracie.

12 Pojem anarchofeminizmus, respektíve jeho anglický ekvivalent ,, anarchofeminism “ používa napríklad autorka Linda Sokačová vo svojom príspevku s názvom Český anarchofeminizmus: Proti hierarchii a privilégiám (Czech Anarchofeminism: Against Hierarchy and Privileges). Pozri bližšie SOKAČOVÁ, L.: Czech Anarchofeminism: Against Hierarchy and Privileges. In: JUSOVÁ, I. - ŠIKLOVÁ, J.: (eds.) Czech feminisms: Perspectives on Gender in East Central Europe. Bloomington - Indiana: Indiana University Press, 2016. s. 144-157.
} 


\section{PRÁVNE ROZPRAVY ON-SCREEN II. - Sekcia dejín a teórie štátu a práva}

online vedecká konferencia - 13. november 2020

Týmito synonymami sú: „,anarcha-feminizmus“ (anglický ekvivalent: „,anarcha-feminism “) alebo tiež „anarcho-feminizmus“ (anglický ekvivalent: „,anarcho-feminism“). Podl'a Julie Tanenbaum sa po prvýkrát objavilo toto pomenovanie ako označenie (spočiatku) intuitívne anarchistického variantu feministického myslenia vo vydaní novín s názvom It Ain't Me, Babe $\mathrm{v}$ auguste roku $1970 .{ }^{13}$

Väzba medzi radikálnym feminizmom a anarchofeminizmom, ba dokonca vyústenie radikálneho feminizmu $\mathrm{V}$ anarchofeminizmus zdôvodňovali $\mathrm{V}$ tom čase prvé anarchofeministky, ktoré sa postupne vyčlenili z radikálne feministických kruhov. Podobne, vtedajšia anarchofeministka Peggy Kornegger vo svojom pamflete napísala, že „[f]eministky boli roky v teórii a praxi nevedomými anarchistkami. “14 Kornegger sa v podstate snažila hl'adat' spojenie medzi anarchizmom a radikálnym feminizmom, pričom došla k poznaniu, že spojenie medzi anarchizmom a feminizmom tu bolo vždy, avšak išlo o nevedomé spojenie. Podl'a nej nastal čas, aby sa z nevedomého spojenia stalo spojenie vedomé. Kornegger totižto spolu s inými anarchofeministkami sedemdesiatych rokov 20. storočia, akými boli napr. Carol Ehrlich a Marian Leighton, považovali rozdiel medzi radikálnym feminizmom a rodiacim sa anarchofeminizmom za otázku stupňa vývoja feministického vedomia, kde anarchofeministické vedomie je vyšším vývojovým stupňom radikálne feministického vedomia. Vel'mi podobne formuluje svoje myšlienky aj d'alšia anarchofeministka tohto obdobia Lynne Farrow, ktorá upozorňuje na skutočnost', že feminizmus je len praktickým vyústením skoršej anarchistickej teórie. Podl’a jej slov tak „[f]eminizmus praktizuje to, čo anarchizmus káže. Dá sa dokonca tvrdit’, že feministky sú jedinými protestujúcimi skupinami, ktoré môžeme označit' za praktizujúcich anarchistov."15 Podporne voči uvedeným názorom prvých anarchofeministiek druhej vlny feminizmu pôsobí aj názor súčasnej anarchofeministky Kythie Kurin. Táto autorka pripomína, že v anarchizme bol naopak stále prítomný silný feministický prvok: „Anarchizmus už nie je tým čím býval pred skúsenost’ou radikálneho feminizmu. [...] Teoreticky vzaté, anarchizmus vždy zahŕňal feminizmus, ale až v posledných rokoch sme skutočne zistili, čo to znamená, a preto sme sa mohli dozvediet' viac o našej účasti [ako anarchofeministiek]. “16 V skutočnosti však tieto názory pri zohl’adnení vývoja

13 Pozri bližšie TANENBAUM, J.: To Destroy Domination in All Forms: Anarcha-Feminist Theory, Organization and Action. 1970-1978. [online]. [cit.2020-09-20] Dostupné na internete:

https://blackrosefed.org/anarcha-feminism-to-destroy-domination-in-all-forms/.

${ }^{14}$ KORNEGGER, P.: Anarchism: The Feminist Connection. Montreal: Kersplebedeb, 2011. s. 11 a nasl.

${ }^{15}$ FARROW, L.: Feminism as Anarchism. London: Black Bear, 1977. s. 1.

16 KURIN, K.: Anarcha-feminism: Why the Hyphen? [online]. [cit.2020-11-24]. Dostupné na internete: https://theanarchistlibrary.org/library/kytha-kurin-anarcha-feminism/. 


\section{PRÁVNE ROZPRAVY ON-SCREEN II. - Sekcia dejín a teórie štátu a práva}

online vedecká konferencia - 13. november 2020

feminizmu a praktických prejavoch anarchistickej teórie môžu byt' problematické a až neudržatel'né, pretože - ako sme už poukázali v bezprostredne predošlej časti nášho príspevku - nie každý feminizmus dospieva k anarchistickým záverom.

Bez ohl'adu na uvedené, už počas druhej vlny feminizmu sa niektoré anarchofeministické predstavitel'ky snažili apelovat' na skutočnost', že politické myslenie a aktivizmus žien majú prirodzené sklony k anarchizmu ako takému. Napríklad, Farrow apelovala na anarchistické sklony žien vo vtedajších podmienkach , predovšetkým preto, lebo ženy sa zasluhujú o konkrétne projekty, akými sú, napríklad potratové kliniky a denné centrá; po druhé, pretože ženy ako v zásade apolitické sa odmietajú zapájat' do politického boja medzi l’avicou a pravicou, respektíve medzi reformizmom a revolúciou. “17 Týmto vlastne chcela podčiarknut' samostatnú aktivitu mnohých žien, ktoré sa odmietli spoliehat' na štát. Podobne sa vyjadrujú aj iné anarchofeministky druhej polovice 20. storočia, ktoré pripomínajú, že ženy boli takpovediac vždy prirodzenými anarchistkami a feminizmus bol od doby svojho vzniku revolučným filozofickým smerom uvažovania ako aj revolučným politickým hnutím. Takýmto príkladom je aj anarchofeministka Elaine Leeder, ktorá tvrdí o vzt’ahu anarchizmu a žien nasledovné: „Zvykne sa hovorit', že ženy často konajú ako anarchistky a pritom si to ani neuvedomujú, zatial' čo niektorí muži samých seba označujú ako anarchistov a nekonajú tak."18 Takýto sled myšlienok nás opätovne vracia $\mathrm{k}$ anarchofeministke Kornegger, ktorá nasledujúcim svojím výrokom dáva do pozornosti inherentne ženám vlastnú revolučnost’ a odpor voči autoritám: „Ak ženské hnutie stálo vôbec za jednou vecou, tak to bol odpor k hierarchickej štruktúre a slepej poslušnosti. Feministky po celej krajine pracovali na prelomení vzoru líder/nasledovatel' v osobných a politických vzt'ahoch.“19 Aj tieto vymedzenia značne odporujú rozšírenému stereotypu žien ako osôb, ktoré sú pasívne, konzervatívne, poslušné a prispôsobivé. Práve anarchofeminizmu výraznejšie napriek všetkými diverzitnými podobami vo feminizme dáva do popredia revolučný obraz ženy, ktorá sa stavia na odpor proti každej autorite, hierarchii a akejkol'vek podobe útlaku. Zároveň však treba upozornit' na skutočnost', že týmito výrokmi v žiadnom prípade nemožno hovorit' o tom, že by spomenuté anarchofeministky predstavovali

\footnotetext{
${ }^{17}$ FARROW, L.: Feminism as Anarchism, s. 19.

${ }^{18}$ LEEDER, E.: Feminism as an Anarchist Process: The Practice of Anarcha-Feminism. [online]. [cit.2020-0927]. Dostupné na internete: https://theanarchistlibrary.org/library/elaine-leeder-feminism-as-an-anarchistprocess/.

19 KORNEGGER, P.: The Spirituality Ripoff. [online]. [cit.2020-09-27]. Dostupné na internete: https:/usa.anarchistlibraries.net/library/peggy-kornegger-the-spirituality-ripoff/.
} 


\section{PRÁVNE ROZPRAVY ON-SCREEN II. - Sekcia dejín a teórie štátu a práva}

online vedecká konferencia - 13. november 2020

esencialistický prvok anarchofeminizmu; naopak, anarchofeminizmu vo svojej historickej a súčasnej podobe bol a je vždy výrazne anti-esencialistickou feministickou teóriou.

Súčasný anarchofeminizmus už od svojho vzniku vytváral predpoklady pre svoj intersekcionálny prístup, čo súvisí so vstrebaním anarchistickej ideológie do feministického vnútra. V nadväznosti na to si treba uvedomit', že anarchizmus ako teoretický postoj sa vymedzuje voči každej podobe (mocenského, a teda hierarchického) útlaku. Anarchofeministické odhodlanie bojovat' proti každej minulej, prítomnej a aj budúcej podobe útlaku odzrkadl'uje nasledovná myšlienka anarchofeministky Carol Ehrlich: „Musíme rozdrvit’ každú podobu útlaku. Nie je to iba slogan, a pritom je to najtažšia úloha zo všetkých. Je to ako dívat' sa na divadlo. Musíme zničit' kulisy a uvedomit' si, že existujú aj iné spôsoby ako robit' veci. Znamená to, že musíme urobit' viac ako reagovat' v naprogramovaných vzburách - musíme konat'. A naše kroky budeme robit' kolektívne, pričom každý bude konat’ autonómne.“20 Zmienená stránka anarchofeministickej vôle čelit' akejkol'vek podobe útlaku sa dostáva aj do myšlienok súčasných anarchofeministiek. Ako príklad, na ktorom uvedenú kontinuitu môžeme demonštrovat' nám môže poslúžit' myšlienka od anarchofeministky Stacy/Sally Darity. Táto anarchofeministka zároveň koriguje nevyhnutnost' boja proti akejkol'vek podobe útlaku spolu s ústrednou úlohou boja proti rodovému útlaku. Podl’a nej je anarchofeminizmus ,proti každému útlaku, nadvláde, a autorite s ohl'adom na rodový útlak, nie pretože by bol tým najdôležitejším, ale pretože na nás vplýva a musíme si s ním poradit'.“21 To však v žiadnom prípade podl'a nej nebráni tomu, aby anarchofeminizmus bol širším, nakol'ko „feminizmus potrebuje byt' širším než len o ženských problémoch. Rodový útlak zahŕňa patriarchát, sexizmus, homofóbiu, heterosexizmus, heteronormativitu, transfóbiu, rodovú binaritu, fatfóbiu + iné problémy týkajúce sa tela, sexuálne násilie, atd'، “22 Rovnako to cíti aj brožúra istej londýnskej anarchofeministickej skupiny, ktorá dáva do pozornosti to, že anarchofeminizmus je ,anti-kapitalistický, anti-rasistický, antisexistický, sex-pozitívny, anti-homofóbny, trans-pozitívny, queer, anti-vekový, pro-ženský, prodetský, silný, anti-policajný, anti-väzenský, revolučný, transformatívny, vel’a potešenia, vel’a srandy, priama akcia, konfrontačný, osobný, politický, kolektívny, milujúci samizdaty, slobodný, taký čo vychádza zdola...“23 pričom pokračuje d’alej v tom, že anarchofeminizmus znamená „byt’

\footnotetext{
${ }^{20}$ EHRLICH, C.: Socialism, Anarchism and Feminism. In DARK STAR COLLECTIVE.: (ed.) Quiet Rumours: An Anarch-Feminist Reader. Oakland, California - Edinburgh, Scotland: AK Press/Dark Star, 2012. s. 64.

${ }^{21}$ STACY/SALLY DARITY.: What is Anarcha-Feminism? [online]. [cit.2020-09-09]. Dostupné na internete: http://www.anarcha.org/sallydarity/whatis.php/.

${ }^{22}$ Tamže.

${ }^{23}$ LONDON ANARCHA-FEMINIST KOLEKTIV.: What the Fuck is Anarcha-feminism anyway? [online]. [cit. 2020-09-09]. Dostupné na internete:
} 


\section{PRÁVNE ROZPRAVY ON-SCREEN II. - Sekcia dejín a teórie štátu a práva}

online vedecká konferencia - 13. november 2020

si vedomým boja za oslobodenie a nenechat', aby sa z boja za ženské oslobodenie stal boj za bielych, strednú vrstvu, zdravých, heterosexuálnych žien v podmienkach kapitalizmu. Ako feministky si musíme uvedomovat’ nielen mužské privilégia, ale aj svoje vlastné.“24 $\mathrm{V}$ inej $\mathrm{z}$ množstva anarchofeministických brožúr je dokonca anarchofeminizmus priamo definovaný ako „súčast' anarchizmu, ktorá sa zameriava na to, aby bola ženská emancipácia v strede boja za dosiahnutie ciel'ov, ktoré predkladá anarchistická teória. Anarchofeminizmus sa snaží o d’alšie rozpracovanie pochopenia ženských rolí pri vytváraní vzt’ahov slobodných od podriadenia a útlaku.“25 Už na základe týchto citátov sa zdá, že rozsah útlakov, na ktorý sa sústred’uje anarchofeminizmus je podstatne širší. Takisto na rozdiel od historickej podoby anarchofeminizmu nie je jeho ciel’ovou kategóriou iba výhradne určená žena robotníckej triedy, ale stáva sa značne inkluzívnym prístupom, ktorý zahrňuje ženy rôznych tried, rás a etnicity, veku, sexuálnej orientácie, rodovej identifikácie, veku, zdravotného stavu, atd’. Zároveň sa zdá, že anarchofeminizmus nevyčleňuje ženský útlak ako samostatný útlak, ale apeluje na jeho previazanost' s inými podobami útlaku súčasnej kapitalistickej spoločnosti. Ak historický anarchizmus hovoril o solidarite žien a robotníckeho hnutia, potom súčasný anarchofeminizmus dáva do popredia solidaritu žien s inými utláčanými skupinami.

Zhrnutím tejto časti nášho príspevku si možno položit' otázku, čo má spoločné historický anarchofeminizmus so súčasným anarchofeminizmom? Predovšetkým ich spájajú tieto podstatné charakteristické rysy: absolútne chápanie slobody jednotlivcov, v ktorom je sloboda mužov, žien či jednotlivcov iných rodov vymedzená bezpodmienečné; vízia egalitárnej spoločnosti, kde rovnost' je skutočnou podmienkou slobody; pozitívny a optimistický postoj k možnostiam splynutia individuálneho a spoločenského, ktorý prekonáva zaužívaný rozpor medzi hodnotami slobody a rovnosti; anti-autoritársky postoj, ktorý súvisí s odmietnutím akejkol’vek podoby autority a vrcholí v anti-etatistický postoj; anti-hierachický postoj, ktorý v širších súvislostiach smeruje k popretiu mocenského základu pre utváranie spoločenských a individuálnych vzt’ahov na rôznych úrovniach a v rôznych sférach života spoločnosti i jednotlivca; anti-inštrumentalistický postoj, ktorý chápe každého jednotlivca ako autonómnu bytost' a účel sám o sebe bez ohl'adu na pohlavie, rod či akékol'vek iné rozlišovacie kritérium; inkluzívny postoj $\mathrm{k}$ divezite, ktorý ráta $\mathrm{s}$ diverzitnými prejavmi

\footnotetext{
http://www.grassrootsfeminism.net/cms/sites/default/files/anarchafeminism.pdf/.

24 Tamže.

${ }^{25}$ Anarcha-feminism. [online] 2001, s. 2. [cit.2020-09-09] Dostupné na internete: https://www.wmmsk.com/media/Library/Фемзины\%20на\%20иностранных\%20языках/English/AnarchaFeminism.pdf/.
} 


\section{PRÁVNE ROZPRAVY ON-SCREEN II. - Sekcia dejín a teórie štátu a práva}

online vedecká konferencia - 13. november 2020

slobody jednotlivcov a prijíma ich do rámca spoločnosti alebo im dokonca vytvára priestor na slobodné prejavy tejto diverzity; anti-organizačný postoj, resp. postoj, ktorý akcentuje potenciálne stránky spontaneity pri utváraní spoločenských a individuálnych vzt’ahov.

Z hl'adiska spôsobu myslenia sa historický anarchofeminizmus rovnako ako súčasný anarchizmus spoločne vyznačujú zahrnutím ideologickej pestrosti východísk do svojho vnútra. Tento znak pri súčasnom anarchofeminizme zdôrazňuje aj Peggy Kornegger, ked’ píše: „Napriek tomu, že seba samú označujem ako anarchofeministku, toto pomenovanie môže v sebe s l'ahkost'ou zahŕňat' socializmus, komunizmus, kultúrny feminizmus, lesbický separatizmus, alebo tucet akýchkol’vek iných politických označení.“26 Takisto obe časové podoby vo svojom vnútri spoločne zdiel'ajú revolučnost'. V nadväznosti na to reprezentujú svoju anti-systémovost', odpor voči kapitalizmu, štátu, autoritárskej podobe náboženstvá, sile spoločensky podporovaných patriarchálnych stereotypov či rasizmu. V oboch podobách anarchofeminizmus zároveň akcentuje silný prvok subjektivity, ktorý vychádza z existenciálnych základov slobody jednotlivca.

Vskutku, anarchofeminizmu už od doby svojho vzniku predstavoval skôr underground než mainstream - a to aj $\mathrm{v}$ rámci feminizmu samotného. Je to $\mathrm{v}$ poriadku, nakol'ko anarchofeminizmus má vytvárat' alternatívny priestor než by využival priestor, ktorý poskytuje sám systém. Redakcia samizdatového anarchofeministického MsFit k tomu poznamenáva: „,V záujme vytvorenia spoločnosti bez rodového útlaku, patriarchátu, rasizmu, tried, ageizmu, ableizmu, homofóbie a všetkých foriem spoločenskej hierarchie, diskriminácie a predsudkov, musíme vytvorit' alternatívy k súčasnému systému. Našou politickou filozofiou je robit' si veci po svojom, vytvárat' zmeny zdola nahor, vytvárat' a udržiavat' solidaritu medzi všetkými utláčanými l’ud’mi a vzájomne sa posilňovat’ v boji proti kapitalizmu, štátu a patriarchátu.،‘27

\section{Prístup historickej podoby anarchofeminizmu k právu}

Právo je v myslení prvých anarchofeministiek úzko späté s problematikou štátu a najmä štátom vynucovanej podoby monogamného manželstva, nukleárnej rodiny, sexuálnej a reprodukčnej neslobody či nerovných miezd. Vedl'a týchto konkrétnych kritík právnych

\footnotetext{
${ }^{26}$ KORNEGGER, P.: Anarchism: The Feminist Connection, s.25.

${ }^{27}$ FEMINIST MAF(I)A.: MsFit: An Anarcha-Feminist Zine. In: Signs: Journal of Women in Culture and Society, Vol. 35, 2009, No. 1. s. 13.
} 


\section{PRÁVNE ROZPRAVY ON-SCREEN II. - Sekcia dejín a teórie štátu a práva}

online vedecká konferencia - 13. november 2020

inštitútov a úprav však anarchofeministky neobchádzajú ani všeobecne teoretické úvahy o negatívnom vplyve práva na hodnotu anarchistickej slobody. V nasledujúcich riadkoch tejto časti nášho príspevku sa zameriame na popredné predstavitel'ky anarchofeministickej teórie práva 19. storočia a prelomu 19. a 20 storočia.

Snád' najznámejšou a najvplyvnejšou ženou anarchistkou bola Emma Goldman. Jej rozpracovanie problematiky ženy podáva na pozadí sexuálnej slobody ženy a vol’nej lásky, ktorá je podl'a jej názoru stránkou slobody jednotlivca. Sloboda mala pre Goldman však omnoho širší význam. Dokonca mala sloboda v jej ponímaní širší význam než bolo schopné samé právo vyjadrit'. Neredukovala ju na textové a formálne vyjadrenie v prameňoch poznávania práva: „Skutočná sloboda nie je obyčajným zdrapom papiera, ktorý je označovaný ako 'ústava', 'občianske práva' alebo 'právo'.“, napísala o vzt’ahu práva a slobody Goldman. ${ }^{28}$ Hlavným dôvodom pre takéto jej tvrdenie je rozlíšenie medzi negatívnou a pozitívnou podobou slobody. Odmieta statickú a abstraktnú povahu negatívnej slobody (,sloboda od“), ktorá je vyjadrená v pozitívnom práve a vyjadruje podporu živej, pozitívnej slobody (,sloboda $\left.\mathrm{k}^{6}\right)$. Pozitívna sloboda podl'a nej nemôže byt' v dostatočnej miere vyjadrená prostredníctvom práva a zabezpečená krokmi štátu, nakol'ko k slobode nemožno prinucovat'.

Právo je v jej vnímaní mocenským donútením, a tak voči nemu - ako voči každému donúteniu - je potrebný a nevyhnutný odpor individuálny alebo spoločenský. S ohl’adom na ženy poukazuje na znenie právnych, ktoré sa obracia poväčšine iba proti ženám. Takým príkladom sú podl'a nej zákony v USA potierajúce prostitúciu. Sankcie z nich plynúce postihujú iba ženy prostitútky. Pasákov, ktorý profitujú z biznisu zo ženským telom nechávajú nepovšimnute bokom a bez trestu. Na tomto príklade demonštrovala, že právo nemožno reformovat'. Teda uvedený problém nie je len o otázka zmeny politiky, ktorá následne môže upravit' text pozitívneho práva, čím je možno dosiahnut' spravodlivejšie spoločenské pomery. Podl'a Goldman je pričina nemožnosti reformovania práva ukrytá v jeho štruktúre. Inými slovami, právo zo svojej podstaty, a teda vo svojej štruktúre predpokladá existenciu donucujúceho útlaku voči slabším - ženám, chudákom alebo l'udom iných rás.

Je tu však aj celkom iný problém. Ten súvisí s efektivitou práva ako donucujúceho a reštriktívneho spoločenského regulátora správania. Goldman poukazuje na paradox $\mathrm{v}$ prípade potierania prostitúcie a hazardu zákonnými zákazmi, ktoré v konečných dôsledkoch vedú k posilneniu prostitúcie: „Prostitúcia a hazard neboli nikdy prospešnejším obchodom

${ }^{28}$ GOLDMAN, E.: The Individual, Society and the State. In SHULMAN, A. K.: (ed.) Red Emma Speaks: An Emma Goldman Reader. 3rd edition. New York: Open Road Integrated Media, 1996. s. 106. 


\section{PRÁVNE ROZPRAVY ON-SCREEN II. - Sekcia dejín a teórie štátu a práva}

online vedecká konferencia - 13. november 2020

odkedy sa proti ním postavil zákon. “29 Tu však nekončí, pretože reštriktívnost’ práva súvisí s d'alšou rovinou, do ktorej má právo inherentnú tendenciu skĺzavat' a ktorú predstavuje jav označovaný ako právny moralizmus. Moralizmus spoločnosti sám o sebe podl’a Goldman vedie k zostrenému podnecovaniu donucujúcej stránky práva. Sama vel'mi citlivo vnímala úroveň, ktorou je zastúpená puritánska morálka v práve Spojených štátov amerických a z tohto dôvodu si bola vedomá negatívnych dôsledkov, ku ktorým vedie právny moralizmus: „Takmer neobmedzené možnosti zla puritánstva prenikajú do pozadia štátu a práva. Predstierajúc, že ochraňuje l'ud pred 'nemorálnost'ou', prenikli štátnou mašinériou a spolu s morálnym opatrovníctvom si uzurpovali cenzúru prostredníctvom práva voči našim názorom, pocitom a dokonca aj správaniu sa. ${ }^{“ 30} \mathrm{~V}$ tejto súvislosti Goldman neopomenula ani kritiku voči ženám. Vadilo jej, že skupiny konzervatívnych, bigotných a fanatických žien sa snažia puritánsku morálku presadit' do obsahu práva. To znamená, to že právo je vo svojom obsahu plné morálky, a to že právo je plné zákazov, ktoré sa hodno vynucovat' razantnost'ou právneho moralizmu. Preto v hovorí o tom, že ,právo s určitost'ou musí byt' ženou: nakol'ko stále zakazuje.“31 Táto dielčia kritika je v skutočnosti súčast’ou širšej kritickej pozície Emmy Goldman, ktorá sa snaží upozornit' na aristofanovský mýtus, že so ženami - a najmä s ich angažovaním v politickom živote - prichádza lepší svet. Goldman prijíma zodpovednost’ za vyslovenú kritiku: „Áno, môžem byt' považovaná za nepriatel'ku ženy; ale ak jej mám pomôct', aby uvidela svetlo, nemôžem sa st’ažovat'، “32 Goldman týmto vyjadruje svoj záver, že nie so ženami prichádza lepší svet, ale naopak s duchovným (vnútorným) oslobodeným každého jednotlivca sa uskutočňujú slobodné pomery v spoločnosti.

Vo svojej eseji s názvom Žiarlivost': Príčina a možná liečba (Jealousy: Causes and a Possible Cure) činí zaujímavé porovnanie, kde dáva lásku a právo do vzájomnej kontrapozície. Inými slovami láska je nezlučitel'ná s právom. Intímnost', sloboda a chápavost' lásky, ktorá umožňuje dvom (prípadne viacerým) l'ud’om medzi sebou vytvorit' neopísatel'né momenty je nehodná striktnej razantnosti príkazov, zákazov a dovolení zo strany zákona. Láska je k právu tým, čím je sloboda k donúteniu. Naopak žiarlivost' má bližšie k právu než k čistej podobe lásky. Žiarlivost’ je prejavom vlastníckych chút’ok, nároku jedného voči druhému či dokonca odhodlania k uplatneniu pomsty, ktorá je vo svojej podstate trestom:

\footnotetext{
${ }^{29}$ GOLDMAN, E.: Woman Suffrage. In: SHULMAN, A. K.: (ed.) Red Emma Speaks: An Emma Goldman Reader, s. 171.

${ }^{30}$ GOLDMAN, E.: The Hypocrisy of Puritanism. In: Tamže, s. 135.

${ }^{31}$ GOLDMAN, E.: Woman Suffrage, In: Tamže, s. 171.

${ }^{32}$ Tamže, s. 176.
} 


\section{PRÁVNE ROZPRAVY ON-SCREEN II. - Sekcia dejín a teórie štátu a práva}

online vedecká konferencia - 13. november 2020

„Žiarlivost' je plná majetníckeho zmyslu a pomsty. V celku sa zhoduje s trestnými ustanoveniami zákonov, ktoré stále vyjadrujú barbarskú predstavu, že trestný čin, ktorý je často výsledkom spoločenských krívd, musí byt’ primerane potrestaný alebo odplatený. “33

Na záver treba pripomenút', že Goldman v istom zmysle uznáva prirodzené právo. Spoliehala sa na to, že sloboda je prirodzeným právom každého občana. Víziu anarchokomunistickej spoločnosti a jej vnútornú reguláciou podmieňovala práve prirodzeným právom.

Iný prístup reprezentuje $\mathrm{v}$ rámci anarchofeminizmu Voltairine de Cleyre. V otázke ženského zrovnoprávnenie jednoznačne odmietla koncept prirodzených práv. Podl'a nej tento koncept nie je schopný sám o sebe vytvorit’ základy pre spoločenskú zmenu. Namiesto toho navrhuje, aby sa ženy spoliehali samé na seba, pretože iba tak môžu ostat' silnými a dosiahnut' požiadavku svojho spoločenského zrovnoprávnenia. Okrem odmietnutia koncepcie prirodzeného práva sa u nej o to viac môžeme stretnút' s odmietnutím pozitívneho práva a justičného systému. Nedôvera $v$ justičný systém ako záruku spravodlivej civilizovanej spoločnosti v nej vyvolal súdny proces s nespravodlivo obvinenými a odsúdenými anarchistami z Haymarketského masakru z roku 1886 v Chicagu. $^{34}$ Po vynesení odsudzujúcich rozsudkov sa de Cleyre rezignovane vyjadrila: „Dovtedy som verila v spravodlivost' amerického právneho poriadku a porotného súdneho systému z ich podstaty. Potom [t.j. po odsúdení páchatel'ov napriek odôvodneným pochybnostiam] som už nikdy nemohla. Hanebnost' tohto súdneho procesu sa zapísala do dejín, a otázka, ktorú prebudil o možnostiach spravodlivosti podl’a práva sa zmenia na hrozivý plač naprieč celým svetom.“‘35 Takýmto spôsobom vyjadrila svoje presvedčenie o tom, že právo nikdy nemôže nadobúdat' vo svojej podstate spravodlivé rozmery a je ako také od spravodlivosti esenciálne odlúčené, a teda aj realisticky odlúčitel'né. De Cleyre predstavuje priamočiaru myšlienkovú líniu, kde právo a justičný systém sú dôkazom toho, že autorita vlády či štátu je v skutočnosti spravidla nespravodlivá. Navyše, Voltairine de Cleyre tvrdila, že práva, ktoré majú náležat’ l’udskej bytosti ako človeku, nikdy nemôžu byt' $\mathrm{s}$ istotou zakotvené a zhmotnené do podoby

\footnotetext{
${ }^{33}$ GOLDMAN, E.: Jealousy: Causes and a Possible Cure. In: SHULMAN, A. K.: (ed.) Red Emma Speaks: An Emma Goldman Reader, s. 187.

${ }^{34} \mathrm{O}$ tom, že išlo pre ňu o významnú udalost' svedčí aj skutočnost', že hrob Voltairine de Cleyre sa nachádza na tom istom cintoríne ako sú pochovaní nespravodlivo odsúdení za Haymarketský masaker. Dokonca sa jej hrob nachádza vedl'a ich hrobov. DELAMOTTE, E.: Refashioning the Mind: The Revolutionary Rhetoric of Voltairine de Cleyre. In: Legacy, Vol. 20, Nos. 1 \& 2, 2003. s. 154.

${ }^{35}$ DE CLEYRE, V.: The Making of an Anarchist. In: HAVEL, H.: (ed.) Selected Works of Voltairine de Cleyre, New York: Mothers Earth Publishing Association, 1914. s. 156.
} 


\section{PRÁVNE ROZPRAVY ON-SCREEN II. - Sekcia dejín a teórie štátu a práva}

online vedecká konferencia - 13. november 2020

pozitívneho práva. Obsah pozitívneho práva je náchylný zmenám, a teda ako každý l'udský výtvor je náchylný k zmenám v závislosti od toho čo sa l’ud’om práve hodí. Právo ako nástroj úpravy a zároveň regulácie l'udských vzt'ahom je teda premenlivým faktorom a jeho obsah pritom stojí na vratkých nohách. Slovom, pozitívne právo nepredstavuje konečnú garanciu l’udských práv. Navyše vláda, ktorá stojí na čele štátu a ktorá tvorí obsah práva nie vždy rešpektuje konsenzus, ktorý vládne medzi občanmi. Politika štátu spolu s právom sú založené na donútení a násilí. Vyjadruje to aj jej nasledujúce vymedzenie anarchizmu vo vzt’ahu k právu: „Anarchizmus hovorí, nevytvárajte zákony týkajúce sa slobody prejavu a prejavy budú slobodné; takže ako náhle urobíte vyhlásenia na papieri o slobode prejavu, príde sto právnikov, ktorí budú dokazovat', že 'sloboda neznamená zneužitie, ani svojvôl'u' a slobodu budú definovat’ mimo existencie.“36

Zaujímavým z pohl’adu kritiky právnej úpravy sa javí aj jej kritika manželstva ako sexuálneho otroctva ženy. Narážala tým na zákonnú úpravu manželstva, ktorá umožňovala manželom znásilňovat' svoje manželky. Takáto podoba manželstva znamenala podl'a de Cleyre, že žena bola držaná v manželstve ako sexuálna otrokyňa svojho manžela, ktorá sa podriad'uje svojmu manželovi vo všetkom. ${ }^{37}$

Súdny proces okolo Haymarketského masakru mal vplyv aj na osobný život anarchistky Lucy Parsons. Jej manžel alebo skôr partner Albert Parsons, bol ako anarchista obvinený a neskôr odsúdený na trest smrti v tomto procese. Lucy Parsons sa priamo nevenuje otázke práva či jednotlivých nespravodlivosti právneho poriadku. Jej prejavy, prednášky, články a eseje majú skôr všeobecný a politický charakter. Napriek uvedenému však v jej myšlienkovom odkaze možno nájst' myšlienky o práve. Akýmsi odrazovým mostíkom môžu byt' v tomto smere myšlienky o vzt'ahu štátu, práva a l'udskej bytosti v jej prednáške s názvom Princípy Anarchizmu (The Principles of Anarchism). Práve v obsahu tejto prednášky vyjadruje nasledujúcu myšlienku: „Hl'adáme oslobodenie spod štátu, pretože vieme, že (právna) moc zasahuje do slobody človeka, zmocňuje sa prirodzených daností a narúša [vzt’ah] človeka a prirodzeného práva; z takéhoto použitia moci štátu pramení takmer každá bieda, chudoba, kriminalita a zmätok, ktoré v spoločnosti existujú.“"38 Takáto myšlienka

\footnotetext{
${ }^{36}$ DE CLEYRE, V.: Anarchism and American Traditions. In: HAVEL, H.: (ed.) Selected works of Voltairine de Cleyre, s. 132.

${ }^{37}$ Pozri bližšie DE CLEYRE, V.: Sex Slavery. In: PRESLEY, S. - SARTWELL, C.: (eds.) Exquisite Rebel: The Essays of Voltairine de Cleyre - Feminist, Anarchist, Genius. Albany: State University of New York Press, 2005. s. 227-237.

${ }^{38}$ PARSONS, L. E.: The Principles of Anarchism: A Lecture. [online]. [cit.2020-11-11]. Dostupné na internete: http://lucyparsons.org/the-principles-of-anarchism.php/.
} 


\section{PRÁVNE ROZPRAVY ON-SCREEN II. - Sekcia dejín a teórie štátu a práva}

online vedecká konferencia - 13. november 2020

reprezentuje tradične anarchistický postoj k právu. Jej odmietavý postoj k právu pramení jednak z mocenského charakteru práva, ktorý narušuje schopnost' rozvinút' prirodzene prítomné dobro $\mathrm{v}$ jednotlivcovi, a takisto $\mathrm{z}$ morálnych dôsledkov pôsobenia práva v spoločnosti, ktoré stavia právo do roviny pričiny všetkého morálneho zla v spoločnosti. Jedinou správnou reakciou je podl'a nej revolučná aktivita, ktorá smeruje proti právu, a teda proti každej „otrockej“ podobe spoločenského vzt’ahu, ktorú vo svojom obsahu právo zakotvuje. Z toho pramení aj anarchistický optimizmu Lucy Parsons, ktorý apeluje na odstránenie práva ako takého: „Tol'ko schopných autorov ukázalo, že nespravodlivé inštitúcie, ktoré spôsobujú tol'ko biedy a utrpenia pre masy, majú svoj koreň v štáte a za celú svoju existenciu vd'ačia moci odvodenej od štátu, ktorej sa už nedá pomôct', ale stále veríme, že ak by bol zajtra odstránený každý jeden zákon, každý jeden list vlastníctva, každý jeden súd a každý jeden policajt alebo vojak, bolo by nám iste lepšie ako teraz. [...] Máme zákony, väzenia, súdy, armády, zbrane a zbrojnice dostatočné na to, aby z nás urobili svätých, keby v skutočnosti boli prevenciou proti zločinu; avšak zlo a skazenost' existujú aj napriek ním, dokonca narastajú, pretože boj medzi triedami je čoraz zúrivejším, bohatstvo je čoraz silnejšie a chudoba je čoraz viac chudobnejšia a zúfalejšia. “39

Takýto postoj je pochopitel’ný aj s ohl'adom na Pittsburský manifest, ktorý napísal jej manžel Albert Parsons spolu s Johannom Mostom, Victorom Drury, Josephom Reifgraber a August Spies a v ktorom je vyjadrená nasledujúca myšlienka v neprospech práva: „Všetko právo je namierené proti pracujúcemu l’udu. “40 Okrem zavrhnutia pozitívneho práva ako výrazu štátnej autority sa však Parsons oprela o koncept prirodzeného práva. Podl'a nej je prirodzené právo jedinou možnou, a zároveň jedinou potrebnou či dostatočnou garanciou regulácie chodu budúcej anarchistickej spoločnosti. Odpor voči pozitívnemu právu a predošlé spochybňovanie amerického právneho poriadku boli Lucy Parsons vyčítané aj v osobných súvislostiach, nakol'ko jej manžel bol obvinený a odsúdený ako jeden z páchatel'ov Haymarketského masakru a Lucy Parsons bola jedna z prvých anarchistov, ktorá verejne poukazovala na rešpektovanie občianskych práv obvinených a poukazovala na to, že nikto by

\footnotetext{
39 Tamže.

${ }^{40}$ Pozri INTERNATIONAL WORKING PEOPLE'S ASSOCIATION.: Manifesto of the International Working Peoples' Association: The Pittsburgh Manifesto to the Workingmen of America. [online]. [cit.2020-11-11]. Dostupné na internete: https:/www.katesharpleylibrary.net/s7h546/.
} 


\section{PRÁVNE ROZPRAVY ON-SCREEN II. - Sekcia dejín a teórie štátu a práva}

online vedecká konferencia - 13. november 2020

nemal byt’ odsúdený a popravený bez náležitého vypočutia a riadneho prejednania jeho veci pred súdom. ${ }^{41}$

Ďalšia anarchofeministka a britská anarchistka Charlotte Wilson sa okrem iného venovala otázke práva a právneho poriadku s ohl'adom na vôl'u zmenit' skostnatenú štruktúru viktoriánskej podoby manželstva a rodiny. Jej myšlienky o práve vychádzajú z analýzy a kritiky práva podl'a Henryho Maine, ktorý v nej poukazoval na právo ako konzervatívny a regresívny faktor vo vývoji morálneho pokroku l’udstva. ${ }^{42}$ Wilson ako pokrokárka si bola vedomá tejto stránky práva, ale takisto ako socialistka poukazovala na záujmovú stránku práva: „Monopol bohatstva by nemal šancu proti zmyslu pre sociálnu spravodlivost’ a potreby l’udstva, pokial' by nebol zakotvený a chránený právom.““33 Č́m dospieva aj k nasledovnej definícii práva: „Právo je vo svojej podstate pokusom určitých osôb vymedzit’ tvrdý a pevný vzor pre správanie iných; a pretože okolnosti, motívy a osobné túžby sa nezhodujú u žiadnych dvoch jednotlivcov, je preto trvalým zdrojom nespravodlivosti a krivdy. “" ${ }^{\text {"4 }} \mathrm{Na}$ jednej strane síce pripomína, že právo sa spočiatku vyformovalo vykryštalizovaním zo spontánnych spoločenských zvykov. V takomto prípade právo obsahovalo vo svojej podstate odkazy k spravodlivosti a morálke. Táto podstata bola však neskôr premenená tak, aby právo vyjadrovalo výhradne záujmy vládnucich. Podl’a Wilson tak právo v dobe kapitalizmu slúži záujmu súkromného vlastníctva: „Právo obklopuje súkromné vlastníctvo svojou vlastnou svätost'ou - svätost'ou, ktorá vyplýva z toho, že ju má predstavovat' - akýmsi záhadným spôsobom - , ktorá sa stáva abstraktne večnou pravdou. 'Nesmiete kradnút', tak ako je zakotvené v zákone, poskytuje osobitú ochranu monopolistom, ktorí vlastnia, a to bez ohl'adu na to ako ich bohatstvo bolo získané a je využívané.“45 Účelom jej kritického rozboru záujmu súkromného vlastníctva $\mathrm{v}$ práve je predovšetkým poukázat' na to ako presadzovanie tohto druhu záujmu vedie k regresu spoločenskej morálky prostredníctvom práva. Inými slovami,

\footnotetext{
${ }^{41}$ ASHBAUGH, C.: Lucy Parsons: American Revolutionary. Chicago: Illinois Labor History Society, 1976. s. 84.

${ }^{42}$ Henry Maine predstavil svoju kritiku práva v knihe s názvom Staroveké právo (Ancient Law), ktorá bola po prvýkrát vydaná v roku 1841. Maine v obsahu tohto diela vyjadruje myšlienku, že právo a štátne orgány skôr brzdili prirodzený vývoj rozumu, spoločenskej morálky a vedeckého pokroku, ku ktorému dospeli radikálnejší myslitelia. V celku poskytovalo toto dielo vedecký základ, ktorý prišiel vhod najmä anarchistickým a socialistickým teoretikom danej doby. Rovnako poukazuje na to, ako právo obmedzovalo postavenie a slobodu žien. K vývoju postaveniu žien podl'a neho pozri bližšie MAINE, H.: Ancient Law: Its connection with the early history of society and its relation to modern ideas. London: John Murray, 1861. s.156 a nasl.

${ }^{43}$ WILLSON, CH. M.: The Principles and Aims of Anarchism. In: Three Essays on Anarchism by Charlotte Wilson. Orkney: Cienfuegos (New Anarchist Library IV), 1979. s. 8.

${ }^{44}$ Tamže, s. 9.

${ }^{45}$ WILSON, CH. M.: Social democracy. In: Three Essays on Anarchism by Charlotte Wilson, s. 18-19.
} 


\section{PRÁVNE ROZPRAVY ON-SCREEN II. - Sekcia dejín a teórie štátu a práva}

online vedecká konferencia - 13. november 2020

podl'a Wilson je právo regresívnym - a nie progresívnym - spoločenským faktorom, ktorý slúži záujmom bohatej triedy na úkor progresívnemu chodu l’udskej spoločnosti.

Vyššie sme uviedli všeobecný pohl’ad Charlotte Wilson na právo. Otázne však ostáva, či dospela aj ku kritike práva a právnej úpravy, ktorá má priamy dopad na postavenie ženy. V tejto súvislosti treba zvlášt’ spomenút' jej kritiku viktoriánskej právnej úpravy manželstva a rodiny, ktorá znamená právne poddanstvo žien. Wilson sa tu prejavila aj ako kritička monogamnej podoby manželstva. Tvrdila, že zákonná úprava monogamného manželstva je škodlivá pre reprodukčné zdravie osôb rovnako ako kapitalistický systém je škodlivým pre morálny vývoj spoločnosti a uspokojovanie všeobecných potrieb l'udstva. Sama totižto videla súvislost' medzi zavedením súkromného vlastníctva a naňho nadväzujúcim zánikom matriarchátu primitívnych komunistických spoločností. V tejto súvislosti si všimla, že so vznikom súkromného vlastníctva súbežne vzniká aj manželov majetnícky nárok na jednu ženu, teda jeho manželku. Vytvorením štátu a zavádzaním práva do spoločnosti sa posilnili sklony garantovat' takýto vývoj do budúcna. Zároveň sa tým vytvoril základ pre právne postavenie ženy v manželstve a rodine, ktoré z nej robí nesvojprávnu osobu, zastúpenú a kontrolovanú tútorskou mocou manžela. Tieto myšlienky vyjadrila vo svojom článku s názvom Rodina ako typ spoločnosti (The Family as a Type of Society), ktoré boli po prvýkrát uverejnené v apríli roku 1886 v novinách Anarchist. ${ }^{46}$ Zároveň v obsahu tohto článku vyjadruje predpoklad, že autorita manžela v rodine tvorí predpoklad pre „ducha nadvlády“ a autoritárskeho zvyku vydávat' príkazy a plnit’ príkazy, ktorý sa z rodiny prenáša na celú spoločnost'. Wilson totižto videla, že štát, podriad'ovanie sa autoritám a právu je nevyhnutne prepojené v dejinách l’udstva s útlakom žien.

\section{Prístup súčasnej podoby anarchofeminizmu k právu}

Prvok nezlučitel'nosti slobody jednotlivcov s právom je príznačný aj pre súčasný anarchofeminizmus. Anarchofeministka Ruby Flick apeluje na túto tézu, ked' vyslovene hovorí, že „sloboda nie je niečím, čo môže byt' nariadené a chránené právom alebo štátmi.“47 Poukazuje na rozpor medzi znakmi formálneho práva vyplývajúceho z autority a slobodou,

\footnotetext{
${ }^{46}$ HINELY, S.: Charlotte Wilson, the „Woman Question“, and the Meanings of Anarchist Socialism in Late Victorian Radicalism. In: International Review of Social History, Vol. 57, 2012, Iss. 1. s. 19.

${ }^{47}$ FLICK, R.: Anarcha-Feminism [online]. [cit.2020-11-10]. Dostupné na internete: https://theanarchistlibrary.org/library/ruby-flick-anarcha-feminism/.
} 


\section{PRÁVNE ROZPRAVY ON-SCREEN II. - Sekcia dejín a teórie štátu a práva}

online vedecká konferencia - 13. november 2020

ktorá je formovaná autenticitou, spontánnost'ou a celistvost'ou tej-ktorej konkrétnej osobnosti a spoločenských podmienok. Teória ako taká musí pri vymedzovaní slobody počítat' $\mathrm{s}$ flexibilitou. Súčasný anarchofeminizmus sa v rámci boja za zrovnoprávnenie žien okrem teórie zameriaval aj na autonómnu prax mimo štátu a mimo práva. V tejto súvislosti tu rozlišujeme umiernený a radikálny anarchofeministický boj za ženské práva. Umiernený boj založený na autonómnom vytváraní komunitných centier na pomoc ženám dáva do pozornosti Kythia Kurin. Naopak, radikálny boj spojený s terorizmom a násilnými skutkami.

Súčasná anarchofeministka Kytha Kurin vo všeobecnosti poukazovala na to ako právny poriadok štátov narúša a ohrozuje prístup žien k umelému prerušeniu tehotenstva a tiež na neschopnost' štátu dôslednejšie riešit' problematiku (sexuálneho) násilia páchaného na ženách. Legislatívu a vôl'u štátu obmedzit’ či dokonca úplne znemožnit' prístup žien k interrupciám opisuje ako „katalyzátor, prečo mnohé ženy začali uvažovat' politicky“ alebo tak ako hovorí: „Ked’ sa objavila legislatíva namierená proti ženám [...] ako vedomý prostriedok posilnenia štátneho vlastníctva ženského tela, mnoho feministiek bolo pripravených pracovat' v politickom hnutí, nakol'ko sme sa ocitli v politickej konfrontácii. [...] intervencia zo strany štátu viedla $\mathrm{k}$ tomu, že intímnost' osobného sa stala politickou. ${ }^{\text {“48 }} \mathrm{A}$ teda Kurin tvrdí, že vzt’ah ženy a jej tela sa stal prostredníctvom práva predmetom dispozície štátnej autority. Poukazuje pritom na zákonnú úpravu obmedzujúcu umelé prerušenie tehotenstva, ktorá sa vo svojej podstate týka ženského tela a v ktorej si štát robí prostredníctvom práva nárok na rozhodovanie o ženskom tele. Takisto znásilnenie je z jej pohl'adu skrytím nárokom štátnej autority na telo ženy či dokonca nárokom na formovanie sexuality. Pridáva sa k názoru niektorých radikálnych feministiek, podl’a ktorých bola právne postihovanie znásilnenia chápané nie ako zločin voči ženám, ale ako konanie, ktoré je spoločenský nebezpečné: ,[...] je na výhodu patriarchálnemu štátu, primät’ svojich občanov, aby sa dívali na znásilnenie ako na zvrátenú podobu sexuálnej túžby, pretože to pomáha poškvrnit' celý pojem sexuality ako ohavnej, a to vynucovaním myšlienky, že telo ako také musí byt' kontrolované a právne upravené štátom. “49

Podl’a Kurin si radikálne feministky pri pomoci ženám preto volili im vlastné cesty, ktoré sa neopierali o štát a vôbec nie o právo. Vytvorili tým autonómnu sféru ženskej spolupráce a vzájomnej pomoci. Pripomína, že radikálne feministky v ovel’a väčšej miere využívali iné ako právne metódy a odmietali uznávat' súdom uložený trest ako dostatočný

\footnotetext{
${ }^{48}$ KURIN, K. Anarcha-feminism: Why the Hyphen?

${ }^{49}$ Tamže.
} 


\section{PRÁVNE ROZPRAVY ON-SCREEN II. - Sekcia dejín a teórie štátu a práva}

online vedecká konferencia - 13. november 2020

dôvod potrestania páchatel'ov znásilnení a násilí na ženách. Kurin poukazuje na spontánne verejné konfrontovanie obvineného muža napríklad bezprostredne na ulici obet'ou a skupinou feministických aktivistiek. Kurin, podobne ako predtým Farrow, spomína dôležitost' úlohy vzdelávania, poradenstva, vzájomnou výmenou vedomostí, zručností a pocitov v poradenských, vzdelávacích a krízových centrách, ktoré autonómne a na komunitnej báze, teda nezávisle od štátu vytvárali radikálne feministky. Tento prístup je zaujímavým aj z tohto hl'adiska, že boj za práva žien a zlepšenie postavenia žien sa môže vykonávat' mimo sféry práva a štátu.

Iný, radikálnejší prístup $\mathrm{k}$ odmietnutiu práva ako cesty boja za ženské zrovnoprávnenie možno nájst' v aktivitách anarchofeministickej krajne l'avicovej skupiny s označením Rote Zora. Jedny z príslušníčok tohto nemeckého hnutia sa v interview vyjadrili, že „,[p]rávo a poriadok sú zásadne proti nám [ženám], aj ked’ sme len t’ažko dosiahli nejaké práva a musíme o ne každý deň bojovat'“ Zároveň k tomu doplnili: „Neexistuje spôsob ako spojit’ boj radikálnych žien s lojalitou voči právu. “50 Hnutie Rote Zora bolo aktívne najmä v rokoch 1974 až 1995. V rámci svojej radikálnej a krajne l'avicovej politickej praxe využívalo viaceré zločinecké či teroristické metódy, ktorými bojovali proti útlaku žien v Nemecku. Medzi ich najznámejšie teroristické útoky patril bombový útok na Spolkový ústavný súd z roku 1975 v čase, kedy sa malo rozhodovat' o obmedzení prístupu žien k interrupciám. Okrem toho sa preslávili ničením obchodov s pornografickým materiálom či podpal'ovaním áut právnikom zastupujúcich protistrany v konaní pred súdmi, ktoré boli podozrivé z páchania trestnej činnosti poškodzujúcej najmä ženy. Takisto bojovali proti obchodníkom s bielym mäsom, v časoch kedy štát nedokázal právnymi cestami a spôsobmi účinne bojovat' proti rozmáhaniu sa takejto trestnej činnosti. Takéto násilné a právo porušujúce aktivity považovali vhodnejšie a účinnejšie v boji za práva žien ako spoliehat' sa na štát a ochranu zo strany zákona. V tomto smere tu môžeme bádat' argument, ktorý poukazuje na neefektívnost' justičných a policajných orgánov pri odhal'ovaní a trestaní násilných trestných činoch na ženách, a tiež medzery $\mathrm{v}$ zákonoch, ktoré spôsobujú nedostatočnú ochranu žien pred násilnými trestnými činmi: „Je legálne, ak muž zbije alebo znásilní svoju manželku. Je legálne, ak obchodníci z bielym mäsom predávajú naše sestry z Tretích krajín nemeckým mužom. Je legálne, ak si žena ničí svoje zdravie a vykonáva monotónnu prácu za minimálnu mzdu. To sú všetko násilné prejavy, ktoré už nehodláme

\footnotetext{
${ }^{50}$ Interview with Rote Zora. In: DARK STAR COLLECTIVE.: (ed.) Quiet Rumours: An Anarch-Feminist Reader, s. 115-116.
} 


\section{PRÁVNE ROZPRAVY ON-SCREEN II. - Sekcia dejín a teórie štátu a práva}

online vedecká konferencia - 13. november 2020

d'alej akceptovat' a ktoré nemôžu byt' zmenené iba kritikou. [...] Preto sabotujeme, bojkotujeme, poškodzujeme a mstíme sa za prežité násilie a ponižovanie útokmi na zodpovedných. ${ }^{\text {(51 }}$

\section{Záver}

V obsahu nami predloženého príspevku sme sa venovali tomu, ako anarchofeminizmus smeruje $\mathrm{k}$ teoretickému odmietnutiu práva ako takého a poukázali sme na jeho praktické vyústenie. V zmysle anarchofeminizmu je právo spoločenským faktorom, ktorý zdôvodňuje moc a hierarchické usporiadanie spoločnosti. Kritická pozícia anarchofeminizmu apeluje $\mathrm{v}$ týchto súvislostiach na samú podstatu práva ako nástroja odporujúceho slobode. Navyše anarchofeminizmus poukazuje na jednotlivé právne inštitúty a právnu úpravu spoločenských vzt’ahov, ktoré zdôvodňujú útlak na ženách. Zároveň si pri rozbore týchto myšlienok treba uvedomit', že anarchofeminizmus neprijíma celkom zhodne tradičné feministickoprávne vymedzenie práva ako inštitúcie patriarchálneho útlaku. Z pohl'adu anarchofeminizmu je takéto definovanie práva len čiastkové a nedostatočné. Dôvodom prečo je tomu tak, je anarchistický ideologický základ anarchofeministického myslenia. Ten kladie zretel' na právo ako z princípu utláčatel'ské, pričom zároveň apeluje na skutočnost', že právo nevyjadruje len jednu podobu útlaku (napr. iba útlak voči ženám), ale celé spektrum spoločenských útlakov. V konkrétnych súvislostiach právo vo svojom vnútri obsahuje celú sumu rozličných a vzájomne prepojených útlakov. Zo spektra útlakov vyjadrených v práve tak možno spomenút' sexizmus, rasizmus, klasizmus, naturizmus, heterosexizmus, ableizmus, ageizmus, fatfóbia, spiecizmus, a iné. Právo ako teoretický koncept a zároveň ako regulátor spoločenského života je takpovediac ohniskom útlakov.

Rímsky rétor Cicero povedal: „Ubi homo, ibi societas; ubi societas, ibi ius. “52 Anarchofeminizmus podobne ako anarchizmus odmieta túto tézu. Snaží sa vytvorit' spoločnost' bez práva. Tak ako si pred štátom volí autonómiu a pred systémom skôr uprednostňuje alternatívu, takisto uprednostňuje spontaneitu pred organizujúcou mocou práva. V historických podobách anarchofeminizmu síce možno vidiet’ príklon ku koncepciám prirodzeného práva, avšak súčasný feminizmus sa opiera o alternatívnu schopnost' budovania

\footnotetext{
51 Tamže, s. 117.

${ }^{52}$ Preklad: „Kde je človek, tam je aj spoločnost'; kde je spoločnost', tam je aj právo“
} 
PRÁVNE ROZPRAVY ON-SCREEN II. - Sekcia dejín a teórie štátu a práva

online vedecká konferencia - 13. november 2020

komunít s využitím svojpomoci, vzájomnej pomoci, bezprostrednosti priamej akcie, vzdelania a ochoty šírit’ a prijímat' informácie.

\section{ZOZNAM BIBLIOGRAFICKÝCH ODKAZOV}

ASHBAUGH, C.: Lucy Parsons: American Revolutionary. Chicago: Illinois Labor History Society, 1976. 288 s. ISBN 0-88286-005-4.

BORDEN, L.: Women and Anarchy In: Heresies: A Feminist Publication on Art and Politics, Vol. 1, 1977, Iss. 2. ISSN 0146-3411, s. 71-77.

BROWN, L. S.: The Politics of Individualism: Liberalism, Liberal Feminism and Anarchism. Montreal - New York - London: Black Rose Books, 1993. 200 s. ISBN 1-895431-78-6.

DE CLEYRE, V.: Anarchism and American Traditions. In: HAVEL, H.: (ed.) Selected Works of Voltairine de Cleyre, New York : Mothers Earth Publishing Association, 1914. s. 118-135.

DE CLEYRE, V.: Sex Slavery. In: PRESLEY, S. - SARTWELL, C.: (eds.) Exquisite Rebel: The Essays of Voltairine de Cleyre - Feminist, Anarchist, Genius. Albany: State University of New York Press, 2005. ISBN 0-7914-6094-0, s. 227-237.

DE CLEYRE, V.: The Making of an Anarchist. In: HAVEL, H.: (ed.) Selected Works of Voltairine de Cleyre, New York : Mothers Earth Publishing Association, 1914. s. 154-163.

DELAmOTTE, E.: Refashioning the Mind: The Revolutionary Rhetoric of Voltairine de Cleyre. In: Legacy, Vol. 20, 2003, Nos. 1 \& 2, 2003. ISSN 0748-4321, s. 153-174.

EHRLICH, C.: Socialism, Anarchism and Feminism. In: DARK STAR COLLECTIVE.: (eds.) Quiet Rumours: An Anarch-Feminist Reader. Oakland, California - Edinburgh, Scotland: AK Press/Dark Star, 2012. ISBN 978-1-84935-103-4, s. 55-66.

FARROW, L.: Feminism as Anarchism. London: Black Bear, 1977. 13 s.

FEMINIST MAF(I)A.: MsFit: An Anarcha-Feminist Zine. In: Signs: Journal of Women in Culture and Society, Vol. 35, 2009, No. 1. ISSN 0097-9740, s. 13-19.

FLICK, R.: Anarcha-Feminism [online]. [cit.2020-11-10]. Dostupné na internete: https://theanarchistlibrary.org/library/ruby-flick-anarcha-feminism/.

FRENETTE, N. L.: On the Women's Movement. In: Our Generation, Vol. 15, 1982, No. 2. s. 21-47. 


\section{PRÁVNE ROZPRAVY ON-SCREEN II. - Sekcia dejín a teórie štátu a práva}

online vedecká konferencia - 13. november 2020

FRENCH, M.: Beyond Power: On Women, Men and Morals. New York: Summit Books, 1985. 640 s. ISBN 0-671-49959-9.

GOLDMAN, E.: Jealousy: Causes and a Possible Cure. In: SHULMAN, A. K.: (ed.) Red Emma Speaks: An Emma Goldman Reader. 3rd edition. New York: Open Road Integrated Media, 1996. ISBN 978-1573924641, s. 186-192.

GOLDMAN, E.: The Hypocrisy of Puritanism. In: SHULMAN, A. K.: (ed.) Red Emma Speaks: An Emma Goldman Reader. 3rd edition. New York: Open Road Integrated Media, 1996. ISBN 978-1573924641, s. 130-136.

GOLDMAN, E.: The Individual, Society and the State. In: SHULMAN, A. K.: (ed.) Red Emma Speaks: An Emma Goldman Reader. 3rd edition. New York: Open Road Integrated Media, 1996. ISBN 978-1573924641, s. 96-107.

GOLDMAN, E.: Woman Suffrage. In: SHULMAN, A. K.: (ed.) Red Emma Speaks: An Emma Goldman Reader. 3rd edition. New York: Open Road Integrated Media, 1996. ISBN 978-1573924641, s. 166-176.

HILDSDOTTE, S.: An Anarcha-feminist's Subjective Perspective of Anarcha-feminism. [online]. [cit.2020-09- 11]. Dostupné na internete:

http://www.spunk.org/library/anarcfem/sp001834.html/.

HINELY, S.: Charlotte Wilson, the „Woman Question“, and the Meanings of Anarchist Socialism in Late Victorian Radicalism. In: International Review of Social History, Vol. 57, 2012, Iss. 1. ISSN 0020-8590, s. 3-36.

INTERNATIONAL WORKING PEOPLE'S ASSOCIATION.: Manifesto of the International Working Peoples' Association: The Pittsburgh Manifesto to the Workingmen of America. [online]. [cit.2020-11-11]. Dostupné na internete:

https://www.katesharpleylibrary.net/s7h546/.

KORNEGGER, P.: Anarchism: The Feminist Connection. Montreal: Kersplebedeb, 2011. 24 s. ISBN 0-9689503-8-8.

KORNEGGER, P.: The Spirituality Ripoff. [online]. [cit.2020-09-27]. Dostupné na internete: https://usa.anarchistlibraries.net/library/peggy-kornegger-the-spirituality-ripoff/.

KURIN, K.: Anarcha-feminism: Why the Hyphen? [online]. [cit.2020-11-24]. Dostupné na internete: https://theanarchistlibrary.org/library/kytha-kurin-anarcha-feminism/.

LEEDER, E.: Feminism as an Anarchist Process: The Practice of Anarcha-Feminism. [online]. [cit.2020-09-27]. Dostupné na internete: 
PRÁVNE ROZPRAVY ON-SCREEN II. - Sekcia dejín a teórie štátu a práva

online vedecká konferencia - 13. november 2020

https://theanarchistlibrary.org/library/elaine-leeder-feminism-as-an-anarchist-process/.

LONDON ANARCHA-FEMINIST KOLEKTIV.: What the Fuck is Anarcha-feminism anyway? [online]. [cit. 2020-09-09]. Dostupné na internete:

http://www.grassrootsfeminism.net/cms/sites/default/files/anarchafeminism.pdf/.

MAINE, H.: Ancient Law: Its connection with the early history of society and its relation to modern ideas. London: John Murray, 1861. $433 \mathrm{~s}$.

MACKINNON, C. A.: Feminism, Marxism, Method, and the State: Toward Feminist Jurisprudence. In: Signs: Journal of Women in Culture and Society, Vol. 8, 1983, No. 4. ISSN 0097-9740, s. 635-658.

MILLER GEARHART, S.: The Future - If There Is One - Is Female. In: MCALLISTER, P.: (ed.) Reweaving the Web of Life: Feminism and Nonviolence. Philadelphia: New Society Publishers, 1982. ISBN 978-0865710160, s. 266-284.

PARSONS, L. E.: The Principles of Anarchism: A Lecture. [online]. [cit.2020-11-11].

Dostupné na internete: http://lucyparsons.org/the-principles-of-anarchism.php/.

PATEMAN, C.: Sex and Power. In Ethics: An International Journal of Social, Political, and Legal Philosophy, Vol. 100, 1990, No. 2. ISSN 0014-1704, s. 398-407.

SOKAČOVÁ, L.: Czech Anarchofeminism: Against Hierarchy and Privileges. In: JUSOVÁ, I. - ŠIKLOVÁ, J.: (eds.) Czech feminisms: Perspectives on Gender in East Central Europe. Bloomington - Indiana: Indiana University Press, 2016. ISBN 9780253021915, s. 144-157.

STACY/SALLY DARITY.: What is Anarcha-Feminism? [online]. [cit.2020-09-09]. Dostupné na internete: http://www.anarcha.org/sallydarity/whatis.php/.

STARHAWK.: Dreaming the Dark: Magic, Sex \& Politics. Boston: Beacon Press, 1988. 243 s. ISBN 0-8070-1025-1.

TANENBAUM, J.: To Destroy Domination in All Forms: Anarcha-Feminist Theory, Organization and Action. 1970-1978. [online]. [cit.2020-09-20] Dostupné na internete: https://blackrosefed.org/anarcha-feminism-to-destroy-domination-in-all-forms/.

WILSON, CH. M.: Social democracy. In: Three Essays on Anarchism by Charlotte Wilson. Orkney: Cienfuegos (New Anarchist Library IV), 1979. s. 11-24.

WILLSON, CH. M.: The Principles and Aims of Anarchism. In: Three Essays on Anarchism by Charlotte Wilson. Orkney: Cienfuegos (New Anarchist Library IV), 1979. s. 6-10. 
PRÁVNE ROZPRAVY ON-SCREEN II. - Sekcia dejín a teórie štátu a práva

online vedecká konferencia - 13. november 2020

Anarcha-feminism. [online] 2001, s. 2. [cit.2020-09-09] Dostupné na internete: https://www.wmmsk.com/media/Library/Фемзины\%20на\%20иностранных\%20языках/Eng lish/Anarcha-Feminism.pdf/.

Interview with Rote Zora. In: DARK STAR COLLECTIVE.: (ed.) Quiet Rumours: An Anarch-Feminist Reader. Oakland, California - Edinburgh, Scotland: AK Press/Dark Star, 2012. ISBN 978-1-84935-103-4, s. 115-120. 